\title{
ENVIRONMENTAL STEWARDSHIP AS A DIMENSION OF A CHRISTIAN STEWARDSHIP ETHIC: VIEWS OF SEMINARY STUDENTS, LECTURERS AND MINISTERS
}

\author{
Author: \\ C S Le Roux ${ }^{1}$

\section{Affiliation:} \\ ${ }^{1}$ College of Education, \\ Department of Educational \\ Foundations, University of \\ South Africa
}

\section{Correspondence to:} Cheryl Le Roux

\section{Postal Address:}

College of Education; Department of Educational Foundations; UNISA 0003

Email:

Irouxcs@unisa.ac.za

Dates:

31 Oct 2016

How to cite this article: Le Roux, C.S., 2016. "Environmental stewardship as a dimension of a Christian stewardship ethic: views of seminary students, lecturers and ministers". KOERS - Bulletin for Christian Scholarship, 81(2). Available at: https://doi.org/10.19108/ KOERS.81.2.2264

\section{Copyright:}

C) 2016. The Author(s).

Published under the Creative Commons Atribution License.
It is not uncommon to find that Christians are blamed for contributing to the destruction of the environment - a view that derives from the Biblical precept that 'man was given dominion over the earth' (cf. Gen. 1:28). The current state of the environment indicates that humankind has indeed ravaged the earth, but it could be argued that this has occurred through greed, covetousness, materialism, competitiveness and short-sightedness which are specific human traits in conflict with God and Christianity. Furthermore, the true significance of the 'dominion over the earth' tenet is invariably overlooked. Having dominion over the earth means that man has the responsibility of representing God on earth; of ruling as His co-regents or, put differently, acting as His stewards or custodians of His creation. It is argued that environmental stewardship is a dimension of the Christian stewardship ethic that is inherent in the Christian faith.

This article reports on research undertaken with ministers, lecturers and students of the United Reformed Church in Southern Africa who were asked to provide their views on Christian stewardship as a requisite component of their role as leaders and aspirant leaders in the Church. Perspectives on environmental stewardship as a dimension of the Christian stewardship ethic were also probed. The research showed that respondents were unanimous in their understanding that Christian stewardship is Biblically founded and mandated and that environmental stewardship is part of that ethic. However, environmental stewardship is inadequately provided for in Church teaching and seminary training programmes. This article examines respondents' views on the above and puts forward ways in which environmental stewardship could be enhanced and promoted.

Key concepts: Christian stewardship; environmental stewardship; environmental literacy; Uniting Reformed Church of Southern Africa

Dit is nie ongewoon dat Christene daarvoor geblameer word dat hulle bydra tot die vernietiging van die omgewing nie -'n beskouing wat afkomstig is van die Bybelse voorskrif dat "die mens heerskappy oor die aarde gegee is" (vgl. Gen. 1:28). Die huidige toestand waarin die omgewing verkeer dui daarop dat die mens inderdaad die aarde verniel het. Daar kan egter aangevoer word dat hebsug, gierigheid, materialisme, mededingendheid en kortsigtigheid, wat spesifieke menslike eienskappe is wat in konflik met God en met Christenskap is, hiertoe aanleiding gegee het. Die ware betekenis van die beginsel van "heerskappy oor die aarde" word boonop keer op keer misgekyk. Om heerskappy oor die aarde te hê beteken dat die mens die verantwoordelikheid het om God se verteenwoordigers op aarde te wees; om as Sy medeheersers te regeer of, anders gestel, as Sy toesighouers of bewaarders van Sy skepping op te tree. Daar word aangevoer dat rentmeesterskap van die omgewing'n dimensie van die Christelike rentmeesterskapsetos is wat eie aan die Christelike geloof is.

Hierdie artikel doen verslag oor navorsing wat onder predikante, dosente en studente van die Verenigende Gereformeerde Kerk in Suider-Afrika gedoen is. Die deelnemers is gevra om hul menings te gee oor Christelike rentmeesterskap as 'n noodsaaklike komponent van hul rol as leiers en aspirantleiers in die kerk. Perspektiewe oor omgewingsrentmeesterskap as ' $\mathrm{n}$ dimensie van die Christelike rentmeesterskapsetos is ook ondersoek. Die navorsing het getoon dat respondente eensgesind was ten opsigte van hul siening dat Christelike rentmeesterskap op die Bybel gegrond is en Bybelse mandaat het, en dat omgewingsrentmeesterskap deel is van daardie etos. Daar word egter nie na behore vir omgewingsrentmeesterskap voorsiening gemaak in die kerk se onderrig- en seminariese opleidingsprogramme nie. Hierdie artikel bestudeer respondente se sienings oor die bogenoemde en stel maniere voor waarop omgewingsrentmeesterskap versterk en bevorder kan word.

Sleutelbegrippe: Christelike rentmeesterskap; omgewingsrentmeesterskap; omgewingsgeletterdheid; Verenigende Gereformeerde Kerk in Suider-Afrika 


\section{INTRODUCTION}

Christianity, in contrast to ancient paganism which it attempted to eradicate at all costs since its inception over 2000 years ago, not only established a dualism of man and nature but also insisted that it is God's will that man exploit nature for his own ends (White, 1967). White continues this line of reasoning by pointing out that modern science and technology are products of Western culture, which is grounded in Christianity, and consequently Christianity should be indicted for the continued exploitation and degradation of the earth. Despite the fact that White's comments were made almost 50 years ago, there are still modern conservationists and environmentalists who hold the view that Christianity is environmentally unfriendly (Bristow, 2001). However, Page (in Esler, 1998: 223-224) and De Witt and Nash (n.d.) argue that Christianity at no point gave licence to the wholesale exploitation of the natural world as posited by White (1967) and acknowledges, with others (Cafaro, 2005; Taliaferro, 2005: 162), that the current state of the environment indicates that humankind has indeed ravaged the earth, but that this has occurred through greed, covetousness, materialism, competitiveness and short-sightedness that are specific human traits in conflict with God and Christianity (Ex., 18:21; Prov., 23:4; Is., 5:8; Matt., 16:26; Luke, 12:15).

As the inspired Word of God, the Bible deals primarily with the relationship between God and humankind and the way to salvation and eternal life. However, the Bible also presents tenets that entreat the protection of the natural and biophysical world in a holistic manner (Bauckman, 2002: 141; Esler, 1998: 223-224; Horrell, Hunt \& Southgate 2008: 223-224). There are many references in the Bible to the wonder and the importance of the biophysical world that we today generally refer to as the 'environment'. These references - although written centuries ago - retain their relevance and point to the heart of many current environmental concerns. Because Christianity is one of the dominant world religions with broad membership, it could be suggested that the Christian community could perhaps have put more effort into taking in hand the actions of its followers, who have contributed to the deterioration and devastation of the natural world as we know it today (Apple, 2009: 98). Christians, the authors believe, should not negate their responsibility towards caring for the environment, but should hold themselves accountable as being trusted stewards of God's creation.

Based on this reasoning, it was decided to establish an understanding and perception of practising ministers, lecturers and ministers-in-training of environmental stewardship (ES) as a dimension of the Christian stewardship (CS) ethic. It was also deemed necessary to establish how seminary curricula treat the issues of environmental literacy (EL), CS and ES and to examine current practices in parishes that could indicate to what extent responsible ES is practised. Using these findings it would be possible to ascertain to what extent practising and aspirant ministers are aware of their Christian ES duty; how they institute or promote an ES ethic amongst parishioners in their community; and where - if required - additional support should be provided to enable ministers to meet their ES obligation.
This article first elaborates on the two concepts environment and stewardship that underpin this study. Given the context of the study, the analysis is done from both a secular and a Biblical perspective. The research context and method are then presented, followed by a discussion of the research results that emanated from a survey undertaken with ministers, students and lecturers of the Uniting Reformed Church in Southern Africa (URCSA). The article provides an opinion of the current status of CS and ES in the Church, congregations and seminaries and suggests ways in which ES could be enhanced, thereby enabling incumbents to better carry out their CS and ES obligations.

\section{CONCEPTS UNDERPINNING THE STUDY}

A discussion of the two focal concepts namely environment with its associated concepts, environmental education (EE) and EL - and stewardship are presented in the following section. An elucidation of the term ES which is a contraction of the two key concepts is also provided.

\subsection{Environment}

Apart from Biblical references to the environment (God's creation), its constitution and how it should be used and cared for, acknowledgement of the necessity of environmental protection and conservation from non-Scriptural contexts has a long history. One of the first recorded regulations regarding environmental protection and conservation is found in the Code of Hammurabi established in the late 1700 sC. In this document - which in today's terms would possibly be called a constitution - there is a section pertaining to agriculture that stipulates the ways in which, for example, date palm trees could be rented, sold, cultivated and protected. The document specifically mentions the prohibition of the destruction of the date palm tree (Katemopolous, 2007-2010). Still, despite apocalyptic concerns raised over the centuries about the way the environment was being exploited (e.g. Malthus [1766-1834] who pointed out that population growth exceeded the ability of the earth to produce subsistence for man (Malthus, 1798:17); and Mill [1806-1873] who held that economic growth should be sacrificed for the sake of the environment, and should limit population to fend off the risk of starvation (Mastin, 2008)), it was only in 1972 at the United Nations Conference on Human Environment organised by the United Nations Environment Programme (UNEP) that the need for a common (global) outlook and definition of the term 'environment' was articulated. In the ensuing definition, environment was described as comprising both natural (biophysical) and human-made components (UNEP, 1972). This explanation has subsequently been taken as the benchmark for most other definitions of the term as established in a variety of contexts.

Mclnnis (in Robinson \& Wolfson, 1982: 3) explains that the environment is not a static entity. A vast number of factors are in constant interaction with each other and influence and impact each other in forming an environment. As such, environment can be conceived as having a plurality - an explanation that is particularly meaningful as it suggests the interrelationship 
between humans and the biophysical God-given and Godcreated natural environment. O'Donoghue's (1993) model of the environment provided in Figure 1 shows the key elements of the UNEP definition of environment.

\section{Power, Policy and Decisions}

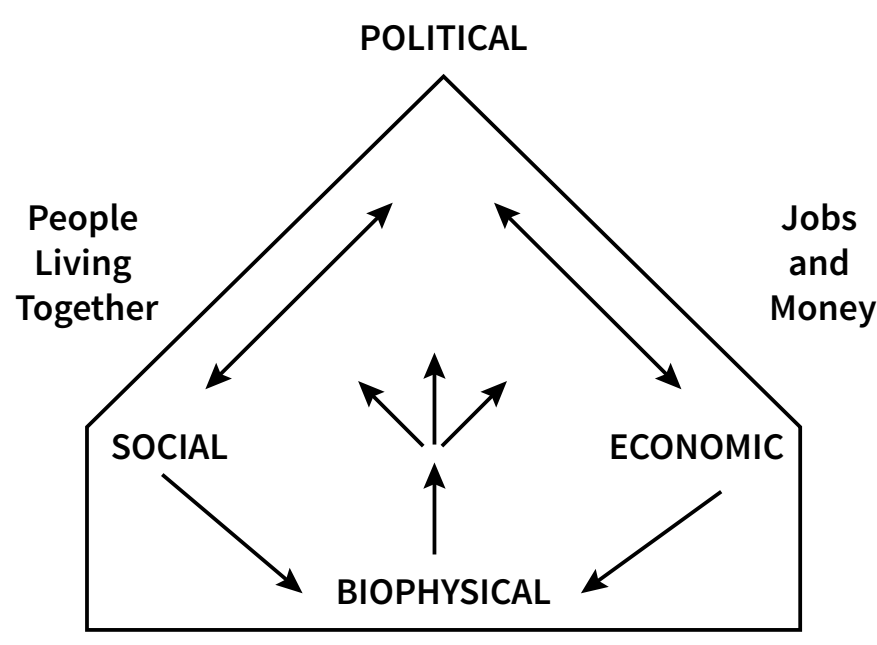

Living things and life support systems

Figure 1: O'Donoghue's model of the environment (1993: 10)

Important aspects relating to the above model of the concept are that

- the environment includes the 'natural' or biophysical environment, and in addition humanity with its social, economic and political constructs that are typical of human society;

- these human-constructed dimensions do not - nor can they - exist separately from the biophysical environment;

- human environments and basic human survival depend entirely on the biophysical environment as a life-support system. Consequently the biophysical dimension of the environment forms the basis of the diagram;

- the political quest for democracy, the economic quest for justice and development, the social quest for reconciliation and peace and the ecological quest for environmental sustainability form a single interrelated agenda;

- the biophysical dimension of the environment can exist independently from the human environment; however, the converse is not true.

Schumacher (in Conradie \& Field, 2000: 13) indicates that modern humanity generally no longer seems to experience itself as part of nature, but as an outside force destined to dominate and conquer it. Nolan (2006), arguing from a Biblical perspective, suggests that because so many have lost touch with nature - God's creation - they have lost touch with God. The biophysical or natural environment, as indicated in the O'Donoghue model, is the foundation of resources and human constructs and is fundamental to human survival. Humankind has the ability to impact the environment in a variety of ways: it can exploit it irrationally and even destroy vast parts of it, as has already occurred, but it can also use it with responsibility and care - as Christian environmental stewards should.

\subsubsection{Environmental education}

As stated previously, reference to the environment as God's creation is clearly entrenched in the Bible, and followers of the Bible are clearly admonished - or educated - on how to care for the environment in various texts in the Scriptures. Apart from the Code of Hammurabi referred to previously, in the modern secular world, one of the first recorded regulations regarding education in relation to the environment is found in 1970 - two years prior to the articulation of the UNEP definition of environment mentioned above. The concept of EE was formalised, in 1970, by the International Union for the Conservation of Nature and Natural Resources (IUCN) the world's oldest and largest international environmental network. Although the IUCN had not yet formulated an authoritative definition of the term 'environment', the organisation's delineation of EE alludes to both dimensions of the environment - the biophysical and the human-made components - mentioned in the UNEP definition.

At the UNEP Tbilisi Conference in 1977 (UNEP, 1977) 12 definitive principles and five goals that spearheaded the notion of the role and function of EE globally were formulated. The goals relate to acquiring a general awareness of the environment, obtaining knowledge of the interrelatedness of both dimensions of the environment, establishing pro-environmental attitudes, and developing skills related to taking action to participate in engaging with and solving environmental problems. With regard to the 12 basic principles, UNEP member countries (of which South Africa is one) were advised to use the established principles as a point of departure to develop unique principles that suited the needs of their distinctive contexts. In South Africa, a total of 22 principles evolved. In the context of this article and the argument put forward that Christians have an ES responsibility, specific principles that apply are those that mention that EE should take the total environment into consideration (cf. Figure 1); biodiversity should be nurtured and pursued through sustainable utilisation of the environment; EE should focus on current and potential environmental issues; various learning environments should be utilised including formal, in-formal and non-formal; concepts that are integral to being able to understand the concept of 'environment' should be taught and affirmed; and an example of responsible environmental behaviour should be set by individuals for others to follow. These comments are supported by the observations of Boersma (1988: 59), Robinson and Wolfson (1982: 4) and Shell, Gallo and Ravenscroft (2009: 463) and affirm the idea that the environment (biophysical and human-induced) can influence and be influenced by humanity in either a positive or negative manner. 
Boersma (ibid.) argues that EE is the development of a process of becoming aware of the natural environment and the influence of people on the environment - the first two goals of EE mentioned previously. EE refers to organised efforts to facilitate learning of how natural environments function and, particularly, how human beings can manage their behaviour and ecosystems in order to live sustainably. Robinson and Wolfson (1982: 4) indicate that EE is a holistic, integrated process that deals with humankind's interrelationship between their natural and man-made surroundings. It promotes amongst citizens the awareness and understanding of the environment, and our relation to it, and encourages concern for responsible actions that are necessary to assure our survival and improve our quality of life - which resonate with the other goals of EE mentioned already.

$\mathrm{EE}$ is about teaching individuals - regardless of their religious affiliation - how environments function and how to manage their behaviour and attitude towards the environment. Their interaction with the biophysical and human dimensions of the environment should be aimed at improving the quality of the environment and treating others with respect, dignity and equanimity, and engaging in life as responsible citizens of this earth.

\subsubsection{Environmental literacy}

The creation of an environmentally literate citizenry is the ultimate goal of EE (Disinger \& Roth, 1992: 7; Elder, 2003: 15). A distinguishing characteristic of the concept has been its 'action' perspective, with Disinger and Roth (1992) defining the concept as follows:

Environmental literacy is essentially the capacity to perceive and interpret the relative health of environmental systems and take appropriate action to maintain, restore, or improve the health of those systems. It tends to be defined in terms of observable behaviours through which people demonstrate in some recognizable form what they have learned: their knowledge of key concepts; the skills acquired; and their disposition, attitude or outlook toward issues.

EL is a multi-dimensional concept; there are a variety of opportunities for establishing the extent of its realisation. It presupposes environmental awareness and knowledge; a pro-environmental attitude; and the intellectual and pragmatic skills needed to incorporate appropriate environmental considerations into daily decisions about lifestyle and the utilisation of environmental resources, and to engage in individual and collective pro-environmental activities (Elder, 2003: 15-17). The resonance between the dimensions of EL and the goals of EE should not be overlooked.

\subsection{Stewards and stewardship duties}

Inherent in the concept of 'stewardship' are the proposed characteristics and assigned duties of a steward. Within a secular context, stewards are caretakers and their stewardship duties involve responsible management, which implies collecting and using information; providing vision and direction; planning and implementing strategies; and putting structures in place to implement the directives and exert influence to ensure that the goals are reached. Examples of stewardship duties include assuming responsibility for the welfare of an aspect of the world, i.e. taking care of human rights, sustainable economic development, conservation or health care. Stewards are accountable for the degree of success of their stewardship, and the success or lack thereof is assessed by determining the wellbeing of the entity of which stewardship is provided (Travis, Egger, Davies \& Mechbal, 2002).

In the Biblical context, a steward is someone entrusted with the general administration of affairs (Gehman, 1970: 906) and is expected to fulfil the duty of custodian or supervisor (1 Pet., 4:10). A steward is entrusted with caring for or managing resources that do not belong to him or her, but for the purpose and at the will of the one who entrusted him or her with this responsibility. The Apostles Paul and Peter (1 Cor., 4:2; Titus, 1:7-9; 1 Pet., 4:10) outline the characteristics and requirements of stewards as individuals who should be trustworthy, blameless, respectful, charitable, self-controlled, upright and disciplined. Their duty is to encourage compliance and oppose wrongdoing.

In the life of each individual Christian, stewardship is seen as the practice of systematic and proportionate giving of time, abilities and material possessions, based on the conviction that these are gifts received in trust from God to be used in His service for the benefit of humanity. Stewardship is thus a Christian's grateful and obedient response to God's redeeming love (Gehman, 1970: 906; Jn., 3:16-17).

\subsection{Environmental stewardship}

The UNEP as a global initiative initiates and coordinates environmental governance and intervention mechanisms as required. The organisation's mission statement is to provide leadership and encourage partnership in caring for the environment by inspiring, informing and enabling nations and peoples to improve their quality of life without compromising the ability of future generations to do likewise (UNEP, 2012). Huong (2010: 1) emphasises that governing the planet's rich and diverse natural resources is an increasingly complex challenge which can only be attempted when a wide range of stakeholders is involved. These governance - or for that matter, stewardship - attempts need to focus on strengthening global, regional, national and local environmental governance to address agreed environmental priorities. The interventions must rest on sound science and technical assistance; international cooperation; national development planning; and international policy setting to enable stakeholders to strengthen their laws and institutions to help them achieve environmental goals, targets and objectives for ameliorating environmental issues. The environmental priority issues span both the biophysical and the human-made dimensions of the environment. The choice of metaphor - governance - in the secular description of humankind's duty to the environment should be noted. Governance over the planet's diverse natural resources implies policy formulation, legislation, monitoring 
and evaluation of progress and, for that matter, a measure of coercion. In contrast, the metaphor of stewardship implies a nurturing and caring for the environment based on individual commitment, persuasion and choice.

From a scriptural perspective, all of creation is important and valuable to God and $\mathrm{He}$ attests to this. Every created thing belongs to Him (Ps., 24:1; Job, 41:11) and was created through Him (Gen., 1; Jn., 1:1-3; Col., 1:16-17). He described the created works (physical and natural) as being good and took pleasure in their creation (Gen., 1:4, 10, 12, 18, 21, 25, \& 31). He is concerned for and provides for His creation (Ps., 104:10-28; Matt., 6:26; Luke, 12:24). It needs to be noted that God recognised the goodness of creation even before the creation of humanity, and its goodness is clearly not dependent on the existence of humanity. God has knowledge of every element of His creation, both human and non-human (Ps., 50:7-12) and furthermore, all of creation was given God's blessing of fruitfulness (Gen., 1:20, 22, 28).

It is generally known that the Bible states that 'man was given dominion over the earth' (Gen., 1:28) which is sometimes glibly taken to indicate Christians' indifferent and exploitive attitude to the use of the environment, but the true significance of this statement is invariably overlooked. The purpose for which humankind was created, is to reflect the image of God Himself and to bring glory to God (Gen., 1:27; 1 Cor., 10:31; Col., 3:17). Having dominion over the earth means that man has the responsibility of representing God on earth; of ruling as His coregents or, put differently, acting as His stewards or custodians (Munroe, 2001: 7). Within this context, man's creation was for stewardship, i.e. to administer and care for the planet (Gen., 1:26-27) and to bring glory to God (Col., 3:17).

In Job, God makes it clear that all of creation is in His hands and not at the whim of humankind (Job, 38:1-39:40). Part of God's provision for the well-being of people is the use of plants, animals and resources to meet humanity's material needs (Bergstrom, 2003). God created plants that were pleasant to look at, provided protection and were good for food (Gen., 2:9). The value of animals as sources of food, beasts of burden and in sacrificial rights is consistently alluded to throughoutboththeNewandOldTestaments.Itisalsomentioned (Gen., 2:12) that God specifically made material and physical resources available to humanity. In Exodus we find a number of unambiguous principles describing God's instructions for the utilisation of His creation. For example the Sabbath principle was introduced, according to which people are required to set aside the seventh day as a day of rest for people and animals (Ex., 20 \& Deut., 5) and in Exodus (23:10-12) and Leviticus (25:2-4) God instructs that all cultivated lands are to be rested and lie fallow in the seventh year (also see 2 Chr., 36:21). These Sabbath principle commandments protect man, beasts and the natural environment from relentless exploitation, ensure their sustainable use and allow for rejuvenation and restoration (DeWitt, 1994; Marshall, 1998). Specific laws providing for the care of plants (Lev., 19:23-25; Deut., 20:19-20) and animals (Ex., 20:18-21; 23:4 \& 5:10-11; Deut., 22:1-4 \& 6-7) are mandated. Principles regarding sanitation and waste disposal are outlined in Leviticus $(17: 1-27,34)$.
The principles mentioned above point to conditions that outline how creation is to be used, but also cared for and protected. God warns through Isaiah that wretchedness will befall those who use His creation in an exploitive manner (Isa., $5: 8)$ and reproaches those who abuse the physical environment (Ezek., 34:2-4, 18; Jer., 2:7). He warns against those who destroy the earth (Lev., 25:23-24; Rev., 11:18). God speaks to humankind through the scriptures, and also through His creation (Ps., 19:1-4; Matt., 6:28-29; Rom., 1:20) and Christians cannot claim ignorance of how creation should be used and cared for. Reumann (1992: 5) claims that exercising ES is expressed by the judicious use and care of creation. As Esler (1998: 219-221) points out, an environmental steward is responsible for:

- conservation of the land, so that it will not go to waste;

- improvement of the land, so that it becomes more productive; and

- care of fellow creatures - the non-human entities.

Clearly this vision ought to stimulate Christians' commitment to tread judiciously on the earth, to use its resources wisely and to nurture and protect it in accordance with God's instructions (Birch in Habel \& Wurst, 2000: 11).

However, is this indeed the perception of and experience in the Christian community? This article reports on research which established the extent to which a sample of ministers, aspirant ministers and their lecturers in the URCSA gauge their own level of EL and ES and their perception of their Christian ES responsibility as part of their mandate as disseminators of God's Word.

\section{RESEARCH METHODOLOGY}

The study followed a mixed-methods research design which drew on quantitative and qualitative research paradigms. The qualitative dimension of the study entailed individual and focus group interviews with serving ministers, seminary students and congregants at various churches of the URCSA in Gauteng. The quantitative dimension of the study comprised a survey undertaken at the Synod meeting of the URCSA held in Hammanskraal, northern Gauteng. Delegates who attended the Synod meeting came from various geographical areas (urban, peri-urban and rural) and all nine provinces in South Africa. Delegates included serving ministers, seminary students and lecturers. The quantitative study results are discussed in this article.

The questionnaire used comprised 130 questions divided into six sections.

- Section A - respondents' biographical and demographic information;

- Section B - respondents' perceptions related to the Biblical foundation of CS and ES and the relationship between the two concepts; 
- Section C - respondents' opinions on the importance of EE in developing EL;

- $\quad$ Section D - respondents' level of EL;

- Section E - respondents' perception of the parishes' or institution's attitude to CS, environmental issues and ES; and

- Section F - students' and lecturers' opinions on the extent to which current seminary training programmes address CS, EL and ES.

In total, 360 questionnaires were distributed at the Synod. Respondents were assured that the information provided would be treated confidentially and that their responses were anonymous. Respondents answered the questions in their own time and returned the completed questionnaires on the last day of the meeting. Sixty completed questionnaires were returned. This represents a 16,67 per cent return rate. Ten of the respondents were students and the others were ministers and lecturers (who are generally also ministers).

The questionnaires were coded by the researcher and submitted for data capturing and processing by a data specialist. The data was analysed using Statistical Analysis System (SAS) software version 92. The data presented by the survey was analysed as follows:

- $\quad$ one-way frequency tables and composite one-way tables;

- scale reliability testing/item analysis on stewardship dimensions;

- correlations between stewardship-dimension scores and biographical details;

- non-parametric approach: two-way frequency tables and Pearson's chi-square tests (or Pearson's exact tests); and

- parametric approach: analysis of variance.

Embedded in the complete spectrum of survey questions were questions that probed particular aspects of CS, ES and EL. These aspects are referred to as stewardship constructs. Frequency tables for the subsets of questionnaire items associated with each stewardship dimension were calculated. The internal consistency reliability of the items and indictors was established by calculating the Cronbach alpha coefficient. The coefficient was greater than 0.7 , indicating scale reliability in all instances. When correlations between biographical details and perceptions of stewardship dimensions were determined, the dependencies were established with Pearson's chi-square test and a Cochran-Armitage trend test.

The findings of the survey are presented and discussed below.

\section{RESEARCH FINDINGS AND DISCUSSION}

The outcome of the survey provided insight into how respondents viewed the stewardship constructs. It also gave insight into respondents' perceptions of how the Church was currently supporting ES as a dimension of CS in practice and in seminary training programmes.

\subsection{Biographical details}

It was thought that certain aspects of respondents' biographical attributes could possibly affect their perceptions of the various stewardship constructs, and consequently specific biographical information was requested. Information on respondents' age, area of residence, exposure to EE during training and careers, the era and type of theological training institution attended and the number of years' experience was obtained.

Significant observations were made in relation to four variables in particular. The sampled respondents were a mature group (75 per cent were older than 41 years), with extensive experience (72 per cent had been in the ministry or lecturing for more than 10 years), whose formal education was mainly completed prior to 1994 (63 per cent) and most had studied at a university (89 per cent). The majority of the respondents ( 64 per cent) had not received formal EE training.

\subsection{Stewardship constructs}

The stewardship constructs and correlations are reported individually.

\subsubsection{Biblical foundations of Christian stewardship and environmental stewardship}

Most ministers, lecturers and students (89 per cent) concurred that both concepts, CS and ES, are Biblically founded, that ES is a dimension of CS, and that both concepts should be actively ministered and practised by professing Christians. Respondents reported that it is a Christian's Biblically founded responsibility to care for creation because of God's own love for His creation; that practising CS is a reflection of a Christian's commitment to God; and that ES does not imply dominance over the environment.

Respondent perceptions of the Biblical perspective of CS and ES are affected by age. Younger respondents perceived the Biblical perspectives on CS and ES more positively; the age-group between 41 and 45 seemed significantly less enthusiastic, but remained positive, while the $46+$ age group seemed to regain the more positive stance (see table 1 ). 
Table 1: Two-way table to illustrate significant dependency/trend between the stewardship dimension of a Biblical perspective on CS and ES and age as biographical attribute

\begin{tabular}{|l|l|l|l|}
\hline Frequency Row Pct & Agree & Agree strongly & Total \\
\hline$<41$ & 750.00 & 750.00 & 14 \\
\hline $41-45$ & 1392.86 & 17.14 & 14 \\
\hline $46+$ & 1979.17 & 520.83 & 24 \\
\hline Total & 39 & 13 & 52 \\
\hline Chi-square statistic=7.27 (0.02) & & \\
\hline
\end{tabular}

A significant dependency and trend relationship between years of experience and perceptions of a Biblical perspective of CS and ES was also established on the 5 per cent level of significance by both the chi-square test and the Cochran-Armitage trend test. This implies that respondent perceptions on the Biblical perspective of CS and ES change with experience (see table 2).

Table 2: Two-way table to illustrate significant dependency/trend between the stewardship dimension of a Biblical perspective on CS and ES and experience as biographical attribute

\begin{tabular}{|l|l|l|l|}
\hline \multicolumn{2}{|l|}{ Exp(q8:,PM: Years' experience) } & BibP1 & Total \\
\hline Frequency Cell Chi-Square & Neutral/Disagree & Agree & \\
\hline$<10$ years & 10.6514 & 130.1212 & $\mathbf{1 4}$ \\
\hline $11-20$ years & 10.9082 & 150.169 & $\mathbf{1 6}$ \\
\hline $21+$ years & 62.2227 & 150.4135 & $\mathbf{2 1}$ \\
\hline Total & $\mathbf{8}$ & $\mathbf{4 3}$ & $\mathbf{5 1}$ \\
\hline Chi-square statistic=4.49 (0.12); Z-statistic=2.00 (0.02) & \\
\hline
\end{tabular}

Furthermore, respondents who trained after 1994 were more positive about the place of CS and ES in the ministry than those who completed their studies before 1994. Respondents with less than 20 years' experience in the ministry were more positive in their perceptions regarding the Biblical approach to CS and ES than the more experienced (see table 3).

Table 3: Two-way table to illustrate significant dependency/trend between the stewardship dimension of a Biblical perspective on CS and ES and time frame when studies were completed as biographical attribute

\begin{tabular}{|l|l|l|l|}
\hline \multicolumn{2}{|l|}{ (q5, PM: Period studies completed) } & BibP1 & Total \\
\hline Frequency Cell Chi-Square & Neutral / Disagree & Agree & \\
\hline$<1994$ & 70.7813 & 250.1454 & 32 \\
\hline$>1994$ & 11.3159 & 180.2448 & 19 \\
\hline $\begin{array}{l}\text { Total } \\
\text { Chi-square statistic=2.49 (0.22); Z-statistic=-1.58 (0.06) }\end{array}$ & $\mathbf{8}$ & $\mathbf{5 1}$ \\
\hline
\end{tabular}


Thus, although there was strong agreement that CS and ES are Biblically founded and that ES is a dimension of CS, the perceptions were influenced by respondents' chronological age, their years of experience and the era in which their seminary studies were completed.

\subsubsection{The significance of environmental literacy and environmental education to environmental stewardship}

EL as a concept seems to have been poorly understood by the respondents. A small number (5 per cent) acknowledged they did not understand what EL means and one-third were uncertain of the meaning. However it was agreed that ministers, students and lecturers should be trained in ES
(72 per cent). There was unanimity amongst respondents about the necessity of teaching EL, CS and ES in the Church. The only question that aroused some measure of disagreement (22 per cent disagreement) was that training in EE (which would raise their level of EL) would positively influence their ministry of ES. EE is critical to the development of EL (UNESCO-UNEP 1978; 1988; UNEP 1998; 2006) and for fostering an understanding of and passion for ES. The unenthusiastic response to the question is troubling and possibly suggests that although ministers, students and lecturers acknowledge the Christian obligation to inform their congregants about their environmental responsibility and lead by example by visibly speaking out about and practising ES, their realisation does not transcend the awareness and knowledge level. The findings in this regard are captured in table 4.

\section{Table 4: Environmental literacy in relation to environmental education and environmental stewardship}

\begin{tabular}{|c|c|c|c|c|c|c|}
\hline Frequency Cell Chi-Square Row \% & $\begin{array}{l}\text { Strongly } \\
\text { Disagree }\end{array}$ & Disagree & Neutral & Agree & $\begin{array}{l}\text { Strongly } \\
\text { Agree }\end{array}$ & Total \\
\hline 50.Understand EL & $\begin{array}{l}0 \\
0.6986 \\
0.00\end{array}$ & $\begin{array}{l}3 \\
2.1401 \\
5.00\end{array}$ & $\begin{array}{l}20 \\
49.216 \\
33.33\end{array}$ & $\begin{array}{l}29 \\
0.6124 \\
48.33\end{array}$ & $\begin{array}{l}8 \\
6.9616 \\
13.33\end{array}$ & 60 \\
\hline $\begin{array}{l}\text { 51.Ministers/students should } \\
\text { understand EL }\end{array}$ & $\begin{array}{l}1 \\
0.1301 \\
1.67\end{array}$ & $\begin{array}{l}0 \\
1.3195 \\
0.00\end{array}$ & $\begin{array}{l}1 \\
2.946 \\
1.67\end{array}$ & $\begin{array}{l}41 \\
1.6634 \\
68.33\end{array}$ & $\begin{array}{l}17 \\
0.374 \\
28.33\end{array}$ & 60 \\
\hline 52.Humankind mandated to ES & $\begin{array}{l}\text { o o. } \\
6986 \\
0.00\end{array}$ & $\begin{array}{l}0 \\
1.3195 \\
0.00\end{array}$ & $\begin{array}{l}3 \\
0.6356 \\
5.00\end{array}$ & $\begin{array}{l}31 \\
0.1911 \\
51.67\end{array}$ & $\begin{array}{l}26 \\
2.0033 \\
43.33\end{array}$ & 60 \\
\hline 53.ES part of a CS responsibility & $\begin{array}{l}0 \\
0.6986 \\
0.00\end{array}$ & $\begin{array}{l}1 \\
0.0774 \\
1.67\end{array}$ & $\begin{array}{l}1 \\
2.946 \\
1.67\end{array}$ & $\begin{array}{l}35 \\
0.0643 \\
58.33\end{array}$ & $\begin{array}{l}23 \\
0.5472 \\
38.33\end{array}$ & 60 \\
\hline $\begin{array}{l}\text { 54.Stewardship is a lifelong } \\
\text { commitment }\end{array}$ & $\begin{array}{l}0 \\
0.6986 \\
0.00\end{array}$ & $\begin{array}{l}0 \\
1.3195 \\
0.00\end{array}$ & $\begin{array}{l}2 \\
1.5796 \\
3.33\end{array}$ & $\begin{array}{l}32 \\
0.07 \\
53.33\end{array}$ & $\begin{array}{l}26 \\
2.0033 \\
43.33\end{array}$ & 60 \\
\hline $\begin{array}{l}\text { 55. Biblical ES to be preached by the } \\
\text { Church }\end{array}$ & $\begin{array}{l}0 \\
0.6986 \\
0.00\end{array}$ & $\begin{array}{l}3 \\
2.1401 \\
5.00\end{array}$ & $\begin{array}{l}1 \\
2.946 \\
1.67\end{array}$ & $\begin{array}{l}29 \\
0.6124 \\
48.33\end{array}$ & $\begin{array}{l}27 \\
2.6916 \\
45.00\end{array}$ & 60 \\
\hline $\begin{array}{l}\text { 56. Student ministers need courses in } \\
\text { Biblical ES }\end{array}$ & $\begin{array}{l}0 \\
0.6869 \\
0.00\end{array}$ & $\begin{array}{l}0 \\
1.2975 \\
0.00\end{array}$ & $\begin{array}{l}3 \\
0.5889 \\
5.08\end{array}$ & $\begin{array}{l}38 \\
0.7665 \\
64.41\end{array}$ & $\begin{array}{l}18 \\
0.0992 \\
30.51\end{array}$ & 59 \\
\hline $\begin{array}{l}\text { 57.Serving ministers need courses in } \\
\text { Biblical ES }\end{array}$ & $\begin{array}{l}1 \\
0.1301 \\
1.67\end{array}$ & $\begin{array}{l}1 \\
0.0774 \\
1.67\end{array}$ & $\begin{array}{l}6 \\
0.3381 \\
10.00\end{array}$ & $\begin{array}{l}35 \\
0.0643 \\
58.33\end{array}$ & $\begin{array}{l}17 \\
0.374 \\
28.33\end{array}$ & 60 \\
\hline $\begin{array}{l}\text { 58. Ministers attend community } \\
\text { environmental concern sessions }\end{array}$ & $\begin{array}{l}1 \\
0.1427 \\
1.69\end{array}$ & $\begin{array}{l}2 \\
0.3803 \\
3.39\end{array}$ & $\begin{array}{l}3 \\
0.5889 \\
5.08\end{array}$ & $\begin{array}{l}30 \\
0.268 \\
50.85\end{array}$ & $\begin{array}{l}23 \\
0.6734 \\
38.98\end{array}$ & 59 \\
\hline
\end{tabular}




\begin{tabular}{|c|c|c|c|c|c|c|}
\hline Frequency Cell Chi-Square Row \% & $\begin{array}{l}\text { Strongly } \\
\text { Disagree }\end{array}$ & Disagree & Neutral & Agree & $\begin{array}{l}\text { Strongly } \\
\text { Agree }\end{array}$ & Total \\
\hline $\begin{array}{l}\text { 59. Environmental training sessions } \\
\text { influence preaching practice }\end{array}$ & $\begin{array}{l}6 \\
40.232 \\
10.00\end{array}$ & $\begin{array}{l}7 \\
24.454 \\
11.67\end{array}$ & $\begin{array}{l}7 \\
1.0837 \\
11.67\end{array}$ & $\begin{array}{l}27 \\
1.2723 \\
45.00\end{array}$ & $\begin{array}{l}13 \\
2.2874 \\
21.67\end{array}$ & 60 \\
\hline $\begin{array}{l}\text { 6o.Ministers are often reminded of } \\
\text { Biblical perspectives on CS }\end{array}$ & $\begin{array}{l}0 \\
0.6869 \\
0.00\end{array}$ & $\begin{array}{l}0 \\
1.2975 \\
0.00\end{array}$ & $\begin{array}{l}5 \\
0.0254 \\
8.47\end{array}$ & $\begin{array}{l}37 \\
0.4919 \\
62.71\end{array}$ & $\begin{array}{l}17 \\
0.2939 \\
28.81\end{array}$ & 59 \\
\hline $\begin{array}{l}\text { 61. Ministers are updated on Biblical } \\
\text { perspectives, ES }\end{array}$ & $\begin{array}{l}0 \\
0.6753 \\
0.00\end{array}$ & $\begin{array}{l}0 \\
1.2755 \\
0.00\end{array}$ & $\begin{array}{l}5 \\
0.0391 \\
8.62\end{array}$ & $\begin{array}{l}34 \\
0.0776 \\
58.62\end{array}$ & $\begin{array}{l}19 \\
0.0002 \\
32.76\end{array}$ & 58 \\
\hline 62. Link exists between CS and ES & $\begin{array}{l}0 \\
0.6753 \\
0.00\end{array}$ & $\begin{array}{l}0 \\
1.2755 \\
0.00\end{array}$ & $\begin{array}{l}4 \\
0.0727 \\
6.90\end{array}$ & $\begin{array}{l}34 \\
0.0776 \\
58.62\end{array}$ & $\begin{array}{l}20 \\
0.0465 \\
34.48\end{array}$ & 58 \\
\hline Total & 9 & 17 & 61 & 432 & 254 & 773 \\
\hline
\end{tabular}

A pair-wise correlation was also established between pairs of stewardship aspects: training in EE, EL and ES. In particular, the perception that CS and ES are Biblically founded is positively related to the significance of training in EE towards EL.
Respondents who had received EE training were positive about the need for such training. The results of this part of the research are presented in table 5 .

Table 5: Correlations between stewardship-dimension scores

Pearson Correlation Coefficients Prob $>|\mathrm{r}|$ under Ho: Rho=0 Number of Observations

\begin{tabular}{|c|c|c|c|c|c|c|c|}
\hline & BibPersp & Training & EL & Environm & Curr-CS & Curr-ES & CurrCS/ES \\
\hline $\begin{array}{l}\text { Biblical perspective, } \\
\text { CS \& ES }\end{array}$ & $\begin{array}{l}1.00000 \\
60\end{array}$ & $\begin{array}{l}0.73436 \\
<.0001 \\
60\end{array}$ & $\begin{array}{l}0.62562 \\
<.0001 \\
60\end{array}$ & $\begin{array}{l}0.02678 \\
0.8405 \\
59\end{array}$ & $\begin{array}{l}0.27267 \\
0.1076 \\
36\end{array}$ & $\begin{array}{l}0.13759 \\
0.4236 \\
36\end{array}$ & $\begin{array}{l}0.21289 \\
0.2125 \\
36\end{array}$ \\
\hline $\begin{array}{l}\text { Training in EE } \\
\text { Ministers training, EE }\end{array}$ & $\begin{array}{l}0.73436 \\
<.0001 \\
60\end{array}$ & $\begin{array}{l}1.00000 \\
60\end{array}$ & $\begin{array}{l}0.79645 \\
<.0001 \\
60\end{array}$ & $\begin{array}{l}0.10599 \\
0.4243 \\
59\end{array}$ & $\begin{array}{l}0.22962 \\
0.1779 \\
36\end{array}$ & $\begin{array}{l}0.03234 \\
0.8515 \\
36\end{array}$ & $\begin{array}{l}0.13539 \\
0.4311 \\
36\end{array}$ \\
\hline $\begin{array}{l}\text { Environmental } \\
\text { literacy Concept, } \\
\text { environmental literacy }\end{array}$ & $\begin{array}{l}0.62562 \\
<.0001 \\
60\end{array}$ & $\begin{array}{l}0.79645 \\
<.0001 \\
60\end{array}$ & $\begin{array}{l}1.00000 \\
60\end{array}$ & $\begin{array}{l}0.16933 \\
0.1998 \\
59\end{array}$ & $\begin{array}{l}0.34689 \\
0.0382 \\
36\end{array}$ & $\begin{array}{l}0.08876 \\
0.6067 \\
36\end{array}$ & $\begin{array}{l}0.22531 \\
0.1864 \\
36\end{array}$ \\
\hline $\begin{array}{l}\text { ES in practice Parish/ } \\
\text { inst. environmental } \\
\text { involvement }\end{array}$ & $\begin{array}{l}0.02678 \\
0.8405 \\
59\end{array}$ & $\begin{array}{l}0.10599 \\
0.4243 \\
59\end{array}$ & $\begin{array}{l}0.16933 \\
0.1998 \\
59\end{array}$ & $\begin{array}{l}1.00000 \\
59\end{array}$ & $\begin{array}{l}0.50552 \\
0.0017 \\
36\end{array}$ & $\begin{array}{l}0.41079 \\
0.0128 \\
36\end{array}$ & $\begin{array}{l}0.47619 \\
0.0033 \\
36\end{array}$ \\
\hline
\end{tabular}




\begin{tabular}{|c|c|c|c|c|c|c|c|}
\hline & BibPersp & Training & EL & Environm & Curr-CS & Curr-ES & CurrCS/ES \\
\hline $\begin{array}{l}\text { Curriculum CS CS in } \\
\text { curriculum }\end{array}$ & $\begin{array}{l}0.27267 \\
0.1076 \\
36\end{array}$ & $\begin{array}{l}0.22962 \\
0.1779 \\
36\end{array}$ & $\begin{array}{l}0.34689 \\
0.0382 \\
36\end{array}$ & $\begin{array}{l}0.50552 \\
0.0017 \\
36\end{array}$ & $\begin{array}{l}1.00000 \\
36\end{array}$ & $\begin{array}{l}0.84932 \\
<.0001 \\
36\end{array}$ & $\begin{array}{l}0.96059 \\
<.0001 \\
36\end{array}$ \\
\hline $\begin{array}{l}\text { Curriculum ES ES in } \\
\text { curriculum }\end{array}$ & $\begin{array}{l}0.13759 \\
0.4236 \\
36\end{array}$ & $\begin{array}{l}0.03234 \\
0.8515 \\
36\end{array}$ & $\begin{array}{l}0.08876 \\
0.6067 \\
36\end{array}$ & $\begin{array}{l}0.41079 \\
0.0128 \\
36\end{array}$ & $\begin{array}{l}0.84932 \\
<.0001 \\
36\end{array}$ & $\begin{array}{l}1.00000 \\
36\end{array}$ & $\begin{array}{l}0.96258 \\
<.0001 \\
36\end{array}$ \\
\hline $\begin{array}{l}\text { Curriculum CS \& ES } \\
\text { CS \& ES in curriculum }\end{array}$ & $\begin{array}{l}0.21289 \\
0.2125 \\
36\end{array}$ & $\begin{array}{l}0.13539 \\
0.4311 \\
36\end{array}$ & $\begin{array}{l}0.22531 \\
0.1864 \\
36\end{array}$ & $\begin{array}{l}0.47619 \\
0.0033 \\
36\end{array}$ & $\begin{array}{l}0.96059 \\
<.0001 \\
36\end{array}$ & $\begin{array}{l}0.96258 \\
<.0001 \\
36\end{array}$ & $\begin{array}{l}1.00000 \\
36\end{array}$ \\
\hline
\end{tabular}

A number of deductions can be made from the statistics presented in table 5. The positive and significant pairwise correlations established between pairs of stewardship dimensions (Biblical perspectives on CS and ES, Training in EE, EL and ES in practice), imply that pair-wise relationships exist between these pairs.

\subsubsection{Attitude to and evidence of Christian stewardship, environmental stewardship and environmental literacy in the parish community and seminary}

This part of the survey established respondents' perceptions of congregations' and seminaries' attitudes to the social and natural environment and the extent to which CS, ES and proenvironmental behaviour is evidenced in their congregations or institutions. Questions in this section of the survey attempted to gauge the level of respondents' EL and to again explore their perception of whether Christians and the Church have an environmental responsibility and should be practitioners of CS and ES.

The survey responses were particularly insightful and of all the sections of the survey this section provided the most disparate responses. Particularly valuable data in respect of what is 'done' in reality, and not what is 'said to be done', provides an accurate picture of the level of commitment to CS, ES and pro-environmental behaviour in the Church and community. Nine questions in particular focused on ES as a construct. Respondents were generally concerned that environmental issues are not adequately addressed in the Church or the community and that the environment is not sufficiently valued. The perception was that if one neglects the environment, one exhibits an attitude of indifference to one's commitment to God.

Six questions specifically addressed the issue of CS and the Church's attitude to and its active involvement in it. The majority of respondents (62 per cent) indicated that more knowledge of
$\mathrm{CS}$ is required. This finding possibly indicates that respondents believe that CS is not being sufficiently advocated or addressed in the Church and current seminary curricula.

The remainder of the questions addressed the level of proenvironmental behaviour and EL exhibited by the Church and the community. Although the responses point to a significant measure of pro-environmental behaviour, the negative responses are possibly more informative. Thirty-seven per cent of the respondents indicated that the community was insufficiently environmentally literate to actively engage of its own accord in environmentally friendly behaviour such as recycling, reducing energy consumption and water wastage, and establishing food gardens to assist feeding schemes for the poor. Other areas where the level of pro-environmental behaviour was probed included whether the Church or community was aware of or used bio-friendly products (biodegradable materials) and whether parish gardeners were sensitive to the local environment and used indigenous plants or those adapted to local climatic conditions. The finding was that the Church and the community were not sufficiently environmentally literate and did not generally exhibit environmentally friendly behaviour.

However, when asked whether ES teaching depends on active involvement in community environmental issues, 14 per cent of the respondents disagreed. This slightly negative response indicates that ministers/lecturers and seminary students question whether teaching or preaching about ES necessarily depends on their active involvement in community-based ES issues - the 'leading by example' principle. Respondents' perceptions of ES in practice are influenced by whether they received EE training or not. Exposure to EE resulted in more positive attitudes to ES in practice. Respondent perceptions on ES in practice differ according to location. Respondents from rural areas are significantly less positive towards ES in practice than urban respondents, which is unusual if one is of the opinion that rural respondents would be closer to and more involved in their environment and ES than city dwellers. 
Table 6: Attitude to and evidence of CS, ES and EL in the parish/seminary

\begin{tabular}{|c|c|c|c|c|c|c|}
\hline Frequency Cell Chi-Square Row Pct & $\begin{array}{l}\text { Strongly } \\
\text { Disagree }\end{array}$ & Disagree & Neutral & Agree & $\begin{array}{l}\text { Strongly } \\
\text { Agree }\end{array}$ & \\
\hline $\begin{array}{l}\text { 63. There is a positive attitude to the natural } \\
\text { environment in the parish or institution }\end{array}$ & $\begin{array}{l}2 \\
0.3545 \\
3.39\end{array}$ & $\begin{array}{l}10 \\
2.9001 \\
16.95\end{array}$ & $\begin{array}{l}19 \\
5.8114 \\
32.20\end{array}$ & $\begin{array}{l}21 \\
0.8549 \\
35.59\end{array}$ & $\begin{array}{l}7 \\
3.0566 \\
11.86\end{array}$ & 59 \\
\hline $\begin{array}{l}\text { 64. There is a positive attitude to the social } \\
\text { environment in the parish or institution }\end{array}$ & $\begin{array}{l}0 \\
3.0378 \\
0.00\end{array}$ & $\begin{array}{l}9 \\
1.6649 \\
15.25\end{array}$ & $\begin{array}{l}17 \\
3.268 \\
28.81\end{array}$ & $\begin{array}{l}26 \\
0.0038 \\
44.07\end{array}$ & $\begin{array}{l}7 \\
3.0566 \\
11.86\end{array}$ & 59 \\
\hline 65. Environment is valued in the parish & $\begin{array}{l}2 \\
0.3545 \\
3.39\end{array}$ & $\begin{array}{l}7 \\
0.2163 \\
11.86\end{array}$ & $\begin{array}{l}18 \\
4.4488 \\
30.51\end{array}$ & $\begin{array}{l}26 \\
0.0038 \\
44.07\end{array}$ & $\begin{array}{l}6 \\
4.0865 \\
10.17\end{array}$ & 59 \\
\hline $\begin{array}{l}\text { 66. It is possible to produce an environmental policy } \\
\text { without effort }\end{array}$ & $\begin{array}{l}4 \\
0.3441 \\
6.90\end{array}$ & $\begin{array}{l}13 \\
9.0454 \\
22.41\end{array}$ & $\begin{array}{l}17 \\
3.5343 \\
29.31\end{array}$ & $\begin{array}{l}18 \\
2.082 \\
31.03\end{array}$ & $\begin{array}{l}6 \\
3.9057 \\
10.34\end{array}$ & 58 \\
\hline $\begin{array}{l}\text { 67. Environmental issues are mentioned in ministry or } \\
\text { lectures }\end{array}$ & $\begin{array}{l}6 \\
2.8886 \\
10.17\end{array}$ & $\begin{array}{l}10 \\
2.9001 \\
16.95\end{array}$ & $\begin{array}{l}8 \\
0.8198 \\
13.56\end{array}$ & $\begin{array}{l}26 \\
0.0038 \\
44.07\end{array}$ & $\begin{array}{l}9 \\
1.4447 \\
15.25\end{array}$ & 59 \\
\hline 68. Environmental days are commemorated & $\begin{array}{l}1 \\
1.3211 \\
1.72\end{array}$ & $\begin{array}{l}4 \\
0.5448 \\
6.90\end{array}$ & $\begin{array}{l}6 \\
2.145 \\
10.34\end{array}$ & $\begin{array}{l}27 \\
0.1212 \\
46.55\end{array}$ & $\begin{array}{l}20 \\
3.5384 \\
4.48\end{array}$ & 58 \\
\hline 69. Parishioners cautioned about environment abuse & $\begin{array}{l}2 \\
0.3257 \\
3.45\end{array}$ & $\begin{array}{l}3 \\
1.3323 \\
5.17\end{array}$ & $\begin{array}{l}12 \\
0.1294 \\
20.69\end{array}$ & $\begin{array}{l}30 \\
0.8933 \\
51.72\end{array}$ & $\begin{array}{l}11 \\
0.3584 \\
18.97\end{array}$ & 58 \\
\hline 70. The gift of creation is praised & $\begin{array}{l}3 \\
0.0001 \\
5.17\end{array}$ & $\begin{array}{l}5 \\
0.1036 \\
8.62\end{array}$ & $\begin{array}{l}11 \\
0.0031 \\
18.97\end{array}$ & $\begin{array}{l}27 \\
0.1212 \\
46.55\end{array}$ & $\begin{array}{l}12 \\
0.1044 \\
20.69\end{array}$ & 58 \\
\hline 71. Parish management is pro-environmental & $\begin{array}{l}4 \\
0.3441 \\
6.90\end{array}$ & $\begin{array}{l}5 \\
0.1036 \\
8.62\end{array}$ & $\begin{array}{l}19 \\
6.1905 \\
32.76\end{array}$ & $\begin{array}{l}20 \\
1.0918 \\
34.48\end{array}$ & $\begin{array}{l}100.7642 \\
17.24\end{array}$ & 58 \\
\hline 72 Parish or institution uses bio-friendly products & $\begin{array}{l}4 \\
0.3441 \\
6.90\end{array}$ & $\begin{array}{l}12 \\
6.7152 \\
20.69\end{array}$ & $\begin{array}{l}11 \\
0.0031 \\
18.97\end{array}$ & $\begin{array}{l}18 \\
2.082 \\
31.03\end{array}$ & $\begin{array}{l}130.0023 \\
22.41\end{array}$ & 58 \\
\hline $\begin{array}{l}\text { 73. Bio-friendly building materials and maintenance } \\
\text { followed }\end{array}$ & $\begin{array}{l}2 \\
0.3257 \\
3.45\end{array}$ & $\begin{array}{l}10 \\
3.0941 \\
17.24\end{array}$ & $\begin{array}{l}17 \\
3.5343 \\
29.31\end{array}$ & $\begin{array}{l}23 \\
0.2006 \\
39.66\end{array}$ & $\begin{array}{l}6 \\
3.9057 \\
10.34\end{array}$ & 58 \\
\hline $\begin{array}{l}\text { 74. Garden managed in an environmentally friendly } \\
\text { way }\end{array}$ & $\begin{array}{l}5 \\
1.3579 \\
8.62\end{array}$ & $\begin{array}{l}9 \\
1.8032 \\
15.52\end{array}$ & $\begin{array}{l}10 \\
0.0617 \\
17.24\end{array}$ & $\begin{array}{l}27 \\
0.1212 \\
46.55\end{array}$ & $\begin{array}{l}7 \\
2.8926 \\
12.07\end{array}$ & 58 \\
\hline $\begin{array}{l}\text { 75. Catering in the parish or institution follows bio- } \\
\text { friendly principles }\end{array}$ & $\begin{array}{l}3 \\
0.0005 \\
5.08\end{array}$ & $\begin{array}{l}7 \\
0.2163 \\
11.86\end{array}$ & $\begin{array}{l}14 \\
0.8161 \\
23.73\end{array}$ & $\begin{array}{l}26 \\
0.0038 \\
44.07\end{array}$ & $\begin{array}{l}9 \\
1.4447 \\
15.25\end{array}$ & 59 \\
\hline
\end{tabular}




\begin{tabular}{|c|c|c|c|c|c|c|}
\hline Frequency Cell Chi-Square Row Pct & $\begin{array}{l}\text { Strongly } \\
\text { Disagree }\end{array}$ & Disagree & Neutral & Agree & $\begin{array}{l}\text { Strongly } \\
\text { Agree }\end{array}$ & \\
\hline 76. Recycling undertaken & $\begin{array}{l}1017.009 \\
17.54\end{array}$ & $\begin{array}{l}12 \\
7.0532 \\
21.05\end{array}$ & $\begin{array}{l}12 \\
0.1764 \\
21.05\end{array}$ & $\begin{array}{l}16 \\
3.1315 \\
28.07\end{array}$ & $\begin{array}{l}7 \\
2.7307 \\
12.28\end{array}$ & 57 \\
\hline 77. Water conserved & $\begin{array}{l}2 \\
0.3545 \\
3.39\end{array}$ & $\begin{array}{l}6 \\
0.0027 \\
10.17\end{array}$ & $\begin{array}{l}13 \\
0.3623 \\
22.03\end{array}$ & $\begin{array}{l}28 \\
0.2085 \\
47.46\end{array}$ & $\begin{array}{l}100.8626 \\
16.95\end{array}$ & 59 \\
\hline 78. Energy conserved & $\begin{array}{l}20.3257 \\
3.45\end{array}$ & $\begin{array}{l}40.5448 \\
6.90\end{array}$ & $\begin{array}{l}16 \\
2.4835 \\
27.59\end{array}$ & $\begin{array}{l}27 \\
0.1212 \\
46.55\end{array}$ & $\begin{array}{l}91.3218 \\
15.52\end{array}$ & 58 \\
\hline 79. Live simply to reduce pressure on the environment & $\begin{array}{l}30.0005 \\
5.08\end{array}$ & $\begin{array}{l}31.4054 \\
5.08\end{array}$ & $\begin{array}{l}23 \\
13.079 \\
38.98\end{array}$ & $\begin{array}{l}25 \\
0.0183 \\
42.37\end{array}$ & $\begin{array}{l}55.2656 \\
8.47\end{array}$ & 59 \\
\hline $\begin{array}{l}\text { 80. Offers recreational activities that promote } \\
\text { appreceation of creation }\end{array}$ & $\begin{array}{l}5 \\
1.3579 \\
8.62\end{array}$ & $\begin{array}{l}8 \\
0.8587 \\
13.79\end{array}$ & $\begin{array}{l}16 \\
2.4835 \\
27.59\end{array}$ & $\begin{array}{l}24 \\
0.0619 \\
41.38\end{array}$ & $\begin{array}{l}5 \\
5.0706 \\
8.62\end{array}$ & 58 \\
\hline 81. Community outreach part of CS & $\begin{array}{l}51.3579 \\
8.62\end{array}$ & $\begin{array}{l}31.3323 \\
5.17\end{array}$ & $\begin{array}{l}14 \\
0.9367 \\
24.14\end{array}$ & $\begin{array}{l}26 \\
0.0222 \\
44.83\end{array}$ & $\begin{array}{l}100.7642 \\
17.24\end{array}$ & 58 \\
\hline 82. Speak out about social / environmental issues & $\begin{array}{l}30.0005 \\
5.08\end{array}$ & $\begin{array}{l}60.0027 \\
10.17\end{array}$ & $\begin{array}{l}80.8198 \\
13.56\end{array}$ & $\begin{array}{l}33 \\
2.0827 \\
55.93\end{array}$ & $\begin{array}{l}91.4447 \\
15.25\end{array}$ & 59 \\
\hline $\begin{array}{l}\text { 83. Speak out to improve social / environmental } \\
\text { awareness }\end{array}$ & $\begin{array}{l}11.3211 \\
1.72\end{array}$ & $\begin{array}{l}13.9467 \\
1.72\end{array}$ & $\begin{array}{l}27.1867 \\
3.45\end{array}$ & $\begin{array}{l}34 \\
3.0317 \\
58.62\end{array}$ & $\begin{array}{l}203.5384 \\
34.48\end{array}$ & 58 \\
\hline 84. Speak out about natural environmental issues & $\begin{array}{l}11.3211 \\
1.72\end{array}$ & $\begin{array}{l}13.9467 \\
1.72\end{array}$ & $\begin{array}{l}27.1867 \\
3.45\end{array}$ & $\begin{array}{l}36 \\
4.5761 \\
62.07\end{array}$ & $\begin{array}{l}181.769 \\
31.03\end{array}$ & 58 \\
\hline 85. Interdenominational CS efforts promoted & $\begin{array}{l}80.6481 \\
6.84\end{array}$ & $\begin{array}{l}71.8537 \\
5.98\end{array}$ & $\begin{array}{l}20 \\
0.1519 \\
17.09\end{array}$ & $\begin{array}{l}51 \\
0.0001 \\
43.59\end{array}$ & $\begin{array}{l}310.7377 \\
26.50\end{array}$ & 17 \\
\hline 86. Interdenominational ES efforts promoted & $\begin{array}{l}02.9863 \\
0.00\end{array}$ & $\begin{array}{l}31.3323 \\
5.17\end{array}$ & $\begin{array}{l}35.649 \\
5.17\end{array}$ & $\begin{array}{l}28 \\
0.2994 \\
48.28\end{array}$ & $\begin{array}{l}248.8993 \\
41.38\end{array}$ & 58 \\
\hline $\begin{array}{l}\text { 87. Parish/institution should raise community } \\
\text { awareness of environment issues }\end{array}$ & $\begin{array}{l}02.9863 \\
0.00\end{array}$ & $\begin{array}{l}05.7735 \\
0.00\end{array}$ & $\begin{array}{l}35.649 \\
5.17\end{array}$ & $\begin{array}{l}31 \\
1.3091 \\
53.45\end{array}$ & $\begin{array}{l}248.8993 \\
41.38\end{array}$ & 58 \\
\hline 88. Addressing environment issues is part of CS & $\begin{array}{l}03.0378 \\
0.00\end{array}$ & $\begin{array}{l}31.4054 \\
5.08\end{array}$ & $\begin{array}{l}35.8214 \\
5.08\end{array}$ & $\begin{array}{l}29 \\
0.4276 \\
49.15\end{array}$ & $\begin{array}{l}248.3853 \\
40.68\end{array}$ & 59 \\
\hline $\begin{array}{l}\text { 89. Environmental issues to be dealt with by the } \\
\text { broader community }\end{array}$ & $\begin{array}{l}1228.001 \\
21.05\end{array}$ & $\begin{array}{l}127.0532 \\
21.05\end{array}$ & $\begin{array}{l}10 \\
0.0374 \\
17.54\end{array}$ & $\begin{array}{l}11 \\
7.6913 \\
19.30\end{array}$ & $\begin{array}{l}120.0691 \\
21.05\end{array}$ & 57 \\
\hline
\end{tabular}




\begin{tabular}{|c|c|c|c|c|c|c|}
\hline Frequency Cell Chi-Square Row Pct & $\begin{array}{l}\text { Strongly } \\
\text { Disagree }\end{array}$ & Disagree & Neutral & Agree & $\begin{array}{l}\text { Strongly } \\
\text { Agree }\end{array}$ & \\
\hline $\begin{array}{l}\text { 90. Christians have an obligation to protect the } \\
\text { environment }\end{array}$ & $\begin{array}{l}\text { O } 2.9863 \\
0.00\end{array}$ & $\begin{array}{l}13.9467 \\
1.72\end{array}$ & $\begin{array}{l}18.9094 \\
1.72\end{array}$ & $\begin{array}{l}21 \\
0.7155 \\
36.21\end{array}$ & $\begin{array}{l}3536.168 \\
60.34\end{array}$ & 58 \\
\hline 91. Christians to be informed about environment issues & $\begin{array}{l}\text { O } 2.9863 \\
0.00\end{array}$ & $\begin{array}{l}0.7735 \\
0.00\end{array}$ & $\begin{array}{l}18.9094 \\
1.72\end{array}$ & $\begin{array}{l}26 \\
0.0222 \\
44.83\end{array}$ & $\begin{array}{l}3124.126 \\
53.45\end{array}$ & 58 \\
\hline $\begin{array}{l}\text { 92. Christians know enough about the environment } \\
\text { and its issues. }\end{array}$ & $\begin{array}{l}20.3545 \\
3.39\end{array}$ & $\begin{array}{l}70.2163 \\
11.86\end{array}$ & $\begin{array}{l}18 \\
4.4488 \\
30.51\end{array}$ & $\begin{array}{l}26 \\
0.0038 \\
44.07\end{array}$ & $\begin{array}{l}64.0865 \\
10.17\end{array}$ & 59 \\
\hline $\begin{array}{l}\text { 93. I would like more information on Christian } \\
\text { environmental stewardship. }\end{array}$ & $\begin{array}{l}51.3579 \\
8.62\end{array}$ & $\begin{array}{l}31.3323 \\
5.17\end{array}$ & $\begin{array}{l}14 \\
0.9367 \\
24.14\end{array}$ & $\begin{array}{l}26 \\
0.0222 \\
44.83\end{array}$ & $\begin{array}{l}100.7642 \\
17.24\end{array}$ & 58 \\
\hline $\begin{array}{l}\text { 94. Emphasising environmental stewardship detracts } \\
\text { from the responsibility of Christian stewardship. }\end{array}$ & $\begin{array}{l}03.0378 \\
0.00\end{array}$ & $\begin{array}{l}31.4054 \\
5.08\end{array}$ & $\begin{array}{l}35.8214 \\
5.08\end{array}$ & $\begin{array}{l}29 \\
0.4276 \\
49.15\end{array}$ & $\begin{array}{l}248.3853 \\
40.68\end{array}$ & 59 \\
\hline $\begin{array}{l}\text { 95. My commitment to God is not affected by } \\
\text { neglecting the environment. }\end{array}$ & $\begin{array}{l}1228.001 \\
21.05\end{array}$ & $\begin{array}{l}127.0532 \\
21.05\end{array}$ & $\begin{array}{l}10 \\
0.0374 \\
17.54\end{array}$ & $\begin{array}{l}11 \\
7.6913 \\
19.30\end{array}$ & $\begin{array}{l}120.0691 \\
21.05\end{array}$ & 57 \\
\hline $\begin{array}{l}\text { 96. Christians are not concerned about environmental } \\
\text { issues. }\end{array}$ & $\begin{array}{l}51.3579 \\
8.62\end{array}$ & $\begin{array}{l}31.3323 \\
5.17\end{array}$ & $\begin{array}{l}14 \\
0.9367 \\
24.14\end{array}$ & $\begin{array}{l}26 \\
0.0222 \\
44.83\end{array}$ & $\begin{array}{l}100.7642 \\
17.24\end{array}$ & 58 \\
\hline Total & 114 & 202 & 385 & 889 & 459 & 39 \\
\hline
\end{tabular}

Chi-square $=427.07$. Probability $($ chi-sq=425.07 $)<0.0001$. Frequency Missing $=361$

In summary, it can be deduced that although respondents were generally positive about the level of CS, ES and EL, and proenvironmental behaviour exhibited by the Church and the community, there was a sizeable number who were critical of whether the Church and communities were sufficiently sensitive to these stewardship constructs and whether they were indeed practising pro-environmental behaviour.

\subsubsection{Christian and environmental stewardship in seminary curricula}

Students and lecturers were asked about their perceptions of whether the current curriculum for URCSA students addresses issues of CS and ES. Respondents indicated that they believed that CS and ES were relevant to their studies, and practising ministers agreed strongly that CS and ES should be incorporated into the curriculum for aspirant ministers (only 6.7 per cent viewed it as unnecessary); that ES is a dimension of CS (only 6.7 per cent disagreed); and that both concepts are Biblically founded and should be taught as such. However when asked to gauge the extent to which stewardship constructs were evidenced in current seminary curricula, it was mentioned that environmental awareness was not prioritised at training institutions. There is an imbalance between the emphasis placed on teaching CS and teaching ES - the latter being mostly neglected. Not much EL was being gained by aspirant ministers through their seminary studies. EL is necessary to enable ministers to enhance environmental awareness, knowledge and skills among congregants. Students are to a limited extent introduced to environmental awareness studies if they choose to take an elective course in EE - but ES is not specifically featured in seminary curricula, despite the fact that the Bible is very specific about taking care of creation in general. It was concluded that the environment is not sufficiently valued nor is it suitably addressed in seminary training. There was a general perception that neglecting to teach about the environment exhibits an attitude of indifference to one's commitment to God.

Lecturers acknowledged that the curriculum focuses primarily on CS without placing an equivalent emphasis on teaching about $\mathrm{ES}$, despite Biblical teachings indicating that since the beginning of time individuals have been tasked to care for the environment which includes both fauna and flora (Gen., 1:26; Lev., 25:23-24; Ezek., 34:2-4). This lack of emphasis on ES disregards God's instruction to care for His creation. It was suggested that ministers and lecturers seem to assume that teachings on CS 
simultaneously provide for and teach an ES ethic. Lecturers indicated that the Biblical concept of stewardship includes the whole of God's creation and that both ES and CS are incorporated in the mandate. ES is a critical feature of CS. The concepts of ES are implied in the URCSA curricula even though some might think that they are not addressed. Both concepts are inseparable and remain intertwined. However, seminary curricula have clearly placed less emphasis on teaching ES and that is why it is currently minimally addressed in the Church. The spiritual nurturing of human beings in the curriculum far exceeds attending to issues of ES. These summarised findings are presented in table 7 .

\section{Table 7: Evidence of Christian stewardship and environmental stewardship in seminary curricula}

\begin{tabular}{|c|c|c|c|c|c|c|}
\hline $\begin{array}{l}\text { Frequency } \\
\text { Cell Chi-Square } \\
\text { Row Pct }\end{array}$ & $\begin{array}{l}\text { Strongly } \\
\text { Disagree }\end{array}$ & Disagree & Neutral & Agree & $\begin{array}{l}\text { Strongly } \\
\text { Agree }\end{array}$ & TOTAL \\
\hline $\begin{array}{l}\text { 97. Students know CS is included in the } \\
\text { curriculum. }\end{array}$ & $\begin{array}{l}2 \\
2.0833 \\
5.56\end{array}$ & $\begin{array}{l}4 \\
0.0786 \\
11.11\end{array}$ & $\begin{array}{l}17 \\
1.4433 \\
47.22\end{array}$ & $\begin{array}{l}9 \\
2.2916 \\
25.00\end{array}$ & $\begin{array}{l}4 \\
0.0122 \\
11.11\end{array}$ & 36 \\
\hline $\begin{array}{l}\text { 98. Students know CS is excluded from the } \\
\text { curriculum. }\end{array}$ & $\begin{array}{l}2 \\
2.3554 \\
5.88\end{array}$ & $\begin{array}{l}6 \\
2.246 \\
17.65\end{array}$ & $\begin{array}{l}17 \\
2.0738 \\
50.00\end{array}$ & $\begin{array}{l}6 \\
4.5761 \\
17.65\end{array}$ & $\begin{array}{l}3 \\
0.2467 \\
8.82\end{array}$ & 34 \\
\hline 99. CS in the curriculum promotes EL concepts. & $\begin{array}{l}0 \\
0.7292 \\
0.00\end{array}$ & $\begin{array}{l}2 \\
0.5639 \\
5.71\end{array}$ & $\begin{array}{l}10 \\
0.4515 \\
28.57\end{array}$ & $\begin{array}{l}16 \\
0.1737 \\
45.71\end{array}$ & $\begin{array}{l}7 \\
2.0324 \\
20.00\end{array}$ & 35 \\
\hline 100. Course content on CS is relevant. & $\begin{array}{l}0 \\
0.7292 \\
0.00\end{array}$ & $\begin{array}{l}1 \\
1.6765 \\
2.86\end{array}$ & $\begin{array}{l}8 \\
1.5396 \\
22.86\end{array}$ & $\begin{array}{l}21 \\
3.0052 \\
60.00\end{array}$ & $\begin{array}{l}5 \\
0.1928 \\
14.29\end{array}$ & 35 \\
\hline 101. Course materials on CS are clearly presented. & $\begin{array}{l}1 \\
0.1006 \\
2.86\end{array}$ & $\begin{array}{l}2 \\
0.5639 \\
5.71\end{array}$ & $\begin{array}{l}18 \\
2.5706 \\
51.43\end{array}$ & $\begin{array}{l}11 \\
0.8101 \\
31.43\end{array}$ & $\begin{array}{l}3 \\
0.2997 \\
8.57\end{array}$ & 35 \\
\hline $\begin{array}{l}\text { 102. Course materials on CS have a practical } \\
\text { orientation. }\end{array}$ & $\begin{array}{l}1 \\
0.0833 \\
2.78\end{array}$ & $\begin{array}{l}5 \\
0.6668 \\
13.89\end{array}$ & $\begin{array}{l}14 \\
0.1297 \\
38.89\end{array}$ & $\begin{array}{l}14 \\
0.0464 \\
38.89\end{array}$ & $\begin{array}{l}2 \\
1.1735 \\
5.56\end{array}$ & 36 \\
\hline 103. Practical sessions of the course are sufficient. & $\begin{array}{l}0 \\
1.4583 \\
0.00\end{array}$ & $\begin{array}{l}14 \\
7.7496 \\
20.00\end{array}$ & $\begin{array}{l}31 \\
1.5923 \\
44.29\end{array}$ & $\begin{array}{l}21 \\
2.129 \\
30.00\end{array}$ & $\begin{array}{l}4 \\
2.1662 \\
5.71\end{array}$ & 70 \\
\hline 104. Practical sessions of the course are valuable. & $\begin{array}{l}0 \\
1.4583 \\
0.00\end{array}$ & $\begin{array}{l}8 \\
0.2269 \\
11.43\end{array}$ & $\begin{array}{l}24 \\
0.0213 \\
34.29\end{array}$ & $\begin{array}{l}31 \\
0.1625 \\
44.29\end{array}$ & $\begin{array}{l}7 \\
0.181 \\
10.00\end{array}$ & 70 \\
\hline 105. Course promotes responsible CS. & $\begin{array}{l}0 \\
0.7292 \\
0.00\end{array}$ & $\begin{array}{l}1 \\
1.6765 \\
2.86\end{array}$ & $\begin{array}{l}13 \\
0.0329 \\
37.14\end{array}$ & $\begin{array}{l}18 \\
0.8901 \\
51.43\end{array}$ & $\begin{array}{l}3 \\
0.2997 \\
8.57\end{array}$ & 35 \\
\hline $\begin{array}{l}\text { 106. Course addresses important components of } \\
\text { CS. }\end{array}$ & $\begin{array}{l}1 \\
0.0833 \\
2.78\end{array}$ & $\begin{array}{l}4 \\
0.0786 \\
11.11\end{array}$ & $\begin{array}{l}9 \\
1.0859 \\
25.00\end{array}$ & $\begin{array}{l}18 \\
0.6778 \\
50.00\end{array}$ & $\begin{array}{l}4 \\
0.0122 \\
11.11\end{array}$ & 36 \\
\hline 107. Course fosters awareness of CS. & $\begin{array}{l}0 \\
0.7292 \\
0.00\end{array}$ & $\begin{array}{l}3 \\
0.0429 \\
8.57\end{array}$ & $\begin{array}{l}11 \\
0.1502 \\
31.43\end{array}$ & $\begin{array}{l}15 \\
0.0235 \\
42.86\end{array}$ & $\begin{array}{l}6 \\
0.8693 \\
17.14\end{array}$ & 35 \\
\hline
\end{tabular}




\begin{tabular}{|c|c|c|c|c|c|c|}
\hline $\begin{array}{l}\text { Frequency } \\
\text { Cell Chi-Square } \\
\text { Row Pct }\end{array}$ & $\begin{array}{l}\text { Strongly } \\
\text { Disagree }\end{array}$ & Disagree & Neutral & Agree & $\begin{array}{l}\text { Strongly } \\
\text { Agree }\end{array}$ & TOTAL \\
\hline $\begin{array}{l}\text { 108. Course provides effective CS preaching } \\
\text { methods. }\end{array}$ & $\begin{array}{l}1 \\
0.0833 \\
2.78\end{array}$ & $\begin{array}{l}3 \\
0.0655 \\
8.33\end{array}$ & $\begin{array}{l}10 \\
0.5801 \\
27.78\end{array}$ & $\begin{array}{l}16 \\
0.0924 \\
44.44\end{array}$ & $\begin{array}{l}6 \\
0.7434 \\
16.67\end{array}$ & 36 \\
\hline $\begin{array}{l}\text { 109. Course encourages active involvement in CS } \\
\text { activities. }\end{array}$ & $\begin{array}{l}1 \\
0.1006 \\
2.86\end{array}$ & $\begin{array}{l}2 \\
0.5639 \\
5.71\end{array}$ & $\begin{array}{l}12 \\
0.0106 \\
34.29\end{array}$ & $\begin{array}{l}16 \\
0.1737 \\
45.71\end{array}$ & $\begin{array}{l}4 \\
0.0029 \\
11.43\end{array}$ & 35 \\
\hline $\begin{array}{l}\text { 110. Course prepares one to deal with controversial } \\
\text { CS issues. }\end{array}$ & $\begin{array}{l}1 \\
0.1006 \\
2.86\end{array}$ & $\begin{array}{l}2 \\
0.5639 \\
5.71\end{array}$ & $\begin{array}{l}9 \\
0.9147 \\
25.71\end{array}$ & $\begin{array}{l}17 \\
0.4625 \\
48.57\end{array}$ & $\begin{array}{l}6 \\
0.8693 \\
17.14\end{array}$ & 35 \\
\hline $\begin{array}{l}\text { 111. CS assignments are properly marked, with } \\
\text { feedback. }\end{array}$ & $\begin{array}{l}1 \\
0.1006 \\
2.86\end{array}$ & $\begin{array}{l}5 \\
0.7756 \\
14.29\end{array}$ & $\begin{array}{l}10 \\
0.4515 \\
28.57\end{array}$ & $\begin{array}{l}16 \\
0.1737 \\
45.71\end{array}$ & $\begin{array}{l}3 \\
0.2997 \\
8.57\end{array}$ & 35 \\
\hline $\begin{array}{l}\text { 112. Students know ES is included in the } \\
\text { curriculum. }\end{array}$ & $\begin{array}{l}1 \\
0.1006 \\
2.86\end{array}$ & $\begin{array}{l}6 \\
2.0294 \\
17.14\end{array}$ & $\begin{array}{l}14 \\
0.2168 \\
40.00\end{array}$ & $\begin{array}{l}13 \\
0.1394 \\
37.14\end{array}$ & $\begin{array}{l}1 \\
2.3532 \\
2.86\end{array}$ & 35 \\
\hline $\begin{array}{l}\text { 113. Students know ES is excluded from the } \\
\text { curriculum. }\end{array}$ & $\begin{array}{l}3 \\
7.072 \\
8.57\end{array}$ & $\begin{array}{l}6 \\
2.0294 \\
17.14\end{array}$ & $\begin{array}{l}12 \\
0.0106 \\
34.29\end{array}$ & $\begin{array}{l}13 \\
0.1394 \\
37.14\end{array}$ & $\begin{array}{l}1 \\
2.3532 \\
2.86\end{array}$ & 35 \\
\hline 114. ES promotes EL. & $\begin{array}{l}0.7292 \\
0.00\end{array}$ & $\begin{array}{l}50.7756 \\
14.29\end{array}$ & $\begin{array}{l}11 \\
0.1502 \\
31.43\end{array}$ & $\begin{array}{l}15 \\
0.0235 \\
42.86\end{array}$ & $\begin{array}{l}40.0029 \\
11.43\end{array}$ & 35 \\
\hline 115. Course content of ES is relevant. & $\begin{array}{l}0.75 \\
0.00\end{array}$ & $\begin{array}{l}20.6276 \\
5.56\end{array}$ & $\begin{array}{l}11 \\
0.2315 \\
30.56\end{array}$ & $\begin{array}{l}18 \\
0.6778 \\
50.00\end{array}$ & $\begin{array}{l}50.1413 \\
13.89\end{array}$ & 36 \\
\hline 116. Course materials for ES are clearly presented. & $\begin{array}{l}10.1006 \\
2.86\end{array}$ & $\begin{array}{l}20.5639 \\
5.71\end{array}$ & $\begin{array}{l}18 \\
2.5706 \\
51.43\end{array}$ & $\begin{array}{l}10 \\
1.3536 \\
28.57\end{array}$ & $\begin{array}{l}40.0029 \\
11.43\end{array}$ & 35 \\
\hline $\begin{array}{l}\text { 117. Course materials for ES have a practical } \\
\text { orientation. }\end{array}$ & $\begin{array}{l}0.75 \\
0.00\end{array}$ & $\begin{array}{l}40.0786 \\
11.11\end{array}$ & $\begin{array}{l}15 \\
0.4103 \\
41.67\end{array}$ & $\begin{array}{l}12 \\
0.5399 \\
33.33\end{array}$ & $\begin{array}{l}50.1413 \\
13.89\end{array}$ & 36 \\
\hline 118. Course promotes responsible ES. & $\begin{array}{l}0.75 \\
0.00\end{array}$ & $\begin{array}{l}30.0655 \\
8.33\end{array}$ & $\begin{array}{l}9 \\
1.0859 \\
25.00\end{array}$ & $\begin{array}{l}20 \\
1.8027 \\
55.56\end{array}$ & $\begin{array}{l}40.0122 \\
11.11\end{array}$ & 36 \\
\hline $\begin{array}{l}\text { 119. Course addresses important components of } \\
\text { ES. }\end{array}$ & $\begin{array}{l}10.0833 \\
2.78\end{array}$ & $\begin{array}{l}30.0655 \\
8.33\end{array}$ & $\begin{array}{l}13 \\
0.0063 \\
36.11\end{array}$ & $\begin{array}{l}14 \\
0.0464 \\
38.89\end{array}$ & $\begin{array}{l}50.1413 \\
13.89\end{array}$ & 36 \\
\hline 120. Course fosters awareness of ES. & $\begin{array}{l}10.1006 \\
2.86\end{array}$ & $\begin{array}{l}11.6765 \\
2.86\end{array}$ & $\begin{array}{l}12 \\
0.0106 \\
34.29\end{array}$ & $\begin{array}{l}14 \\
0.0121 \\
40.00\end{array}$ & $\begin{array}{l}72.0324 \\
20.00\end{array}$ & 35 \\
\hline 121. Course provides good ES preaching methods. & $\begin{array}{l}10.1201 \\
2.94\end{array}$ & $\begin{array}{l}20.5021 \\
5.88\end{array}$ & $\begin{array}{l}12747 \mathrm{E}- \\
835.29\end{array}$ & $\begin{array}{l}15 \\
0.0706 \\
44.12\end{array}$ & $\begin{array}{l}4144 \mathrm{E}-7 \\
11.76\end{array}$ & 34 \\
\hline
\end{tabular}




\begin{tabular}{|c|c|c|c|c|c|c|}
\hline $\begin{array}{l}\text { Frequency } \\
\text { Cell Chi-Square } \\
\text { Row Pct }\end{array}$ & $\begin{array}{l}\text { Strongly } \\
\text { Disagree }\end{array}$ & Disagree & Neutral & Agree & $\begin{array}{l}\text { Strongly } \\
\text { Agree }\end{array}$ & TOTAL \\
\hline 122. Course encourages active ES. & $\begin{array}{l}10.1006 \\
2.86\end{array}$ & $\begin{array}{l}20.5639 \\
5.71\end{array}$ & $\begin{array}{l}11 \\
0.1502 \\
31.43\end{array}$ & $\begin{array}{l}16 \\
0.1737 \\
45.71\end{array}$ & $\begin{array}{l}50.1928 \\
14.29\end{array}$ & 35 \\
\hline 123. Course addresses controversial ES issues. & $\begin{array}{l}10.1006 \\
2.86\end{array}$ & $\begin{array}{l}20.5639 \\
5.71\end{array}$ & $\begin{array}{l}10 \\
0.4515 \\
28.57\end{array}$ & $\begin{array}{l}16 \\
0.1737 \\
45.71\end{array}$ & $\begin{array}{l}60.8693 \\
17.14\end{array}$ & 35 \\
\hline 124. ES assignments are marked with feedback. & $\begin{array}{l}10.1006 \\
2.86\end{array}$ & $\begin{array}{l}20.5639 \\
5.71\end{array}$ & $\begin{array}{l}12 \\
0.0106 \\
34.29\end{array}$ & $\begin{array}{l}14 \\
0.0121 \\
40.00\end{array}$ & $\begin{array}{l}60.8693 \\
17.14\end{array}$ & 35 \\
\hline Total & 22 & 102 & 373 & 435 & 124 & 1056 \\
\hline
\end{tabular}

Because of less emphasis on ES at the seminaries and the fact that it is not a compulsory module in the curriculum, it appears that most students receive no specific training in ES for the ministry. It is therefore possible to suggest that ES is neglected in the training of aspirant ministers in the URCSA.

\section{CONCLUSIONS AND RECOMMENDATIONS}

Respondents were unanimous that ES is a dimension of CS and that both concepts should be fundamental to a Christian ethic. Although humankind has dominion over the earth, they are mandated to live in harmony with each other (CS) as well as nature (ES) and to use nature judiciously (Gen., 2:15). The ultimate ownership of all things rests with God (Job, 38:1-39), and His people are required to zealously tend His creation which has been entrusted to them. There is no greater justification needed for Christians to meet their CS and ES duties.

However, the research showed that currently ES features inadequately in the ministry of the Church, in the parishes and in theological seminary curricula. It is clear that currently there is a distinct need to improve the integration of ES into the ministry and into seminary training programmes. As a start, ministers should enhance ES among congregants by propagating societal values that encourage people to live parsimoniously and to tread lightly on the environment. Curricula in seminaries should include and promote learning about the environment to enhance students' understanding of the scope and depth of their Christian ES duties. To facilitate this, ES should be embedded in seminary programmes as a dimension of teaching on CS.

Environmental care is at the root of true Christian service. To preach a Gospel proclaiming salvation for humankind without placing this salvation within the broader context of God's love and concern for the entire creation is not bringing the full Gospel. Caring for the souls of people without caring for their total well-being gives witness of a dead faith. Neuhaus (1997:20-
25) and Schaeffer (1970) indeed capture these sentiments in their comments that too many philosophers and religious thinkers, including serious Christians, have thought it necessary to look outside the Christian tradition for a way of understanding the nature and destiny of the universe, when a more convincing account can be developed from within the tradition. They believe that this is especially true when it comes to the environment. Nature is God's creation and there should be none more qualified to speak wisely and act prudently when discussing care for it than Christians. ${ }^{1}$ 


\section{REFERENCES}

APPLE, M. W. 2009. Some ideas on interpreting the right: on doing critical educational work in conservative times. Education, citizenship and social justice, $4(2): 87-101$.

BERGSTROM, JC. 2003. Principles of Christian environmental ethic: with applications to agriculture, natural resources, and the environment. http://www. leaderu.com/science/bergstrom-enviroethics.html Date of access 20 December 2014.

BIBLE. 1982. Good News Bible: Today's English Version. London: William Collins \& Sons.

BOERSMA, K. 1988. The educational side of environmental education, in S. Briceno $\&$ D. Pitt (eds.). New ideas in environmental education. Kent: Croom Helm/IUCN $57-78$.

BRISTOW, P. 2001. The root of our ecological crisis. Journal of Creation, 15:76-79.

BAUCKMAN, R. J. 2002. God and the crisis of freedom: Biblical and contemporary perspectives. Louisville: John Knox Berry.

CAFARO, P.J. 2005. Gluttony, arrogance, greed and apathy: an exploration of environmental vice, in R. Sandler and P. Cafaro (eds.), Environmental virtue ethics. Lanham: Rowland \& Littlefield. 135-158.

CONRADIE, E \& FIELD, D. 2000. A rainbow over land. Pretoria: Salty Print.

DeWITT, C. B. \& NASH, B., n.d. Earth-Wise: A Biblical response to environmental issues. Grand Rapids: CRC Publications.

DISINGER, J. F. \& ROTH, C. E. 1992. Environmental Literacy. http://www.ericdigests. org/1992-1/literacy.htm Date of access 21 May 2013.

ELDER, J.L. 2003. A field guide to environmental literacy: making strategic investments in environmental education. www.naaee.org Date of access 22 July 2012.

ESLER, P. F. 1998, Christianity for the twenty-first century. Edinburgh: Clark.

GEHMAN, H.S. 1970. The New Westminster Dictionary of the Bible. Philadelphia: Westminster Press.

HABEL, N.C. \& WURST, S. 2000. The earth story in Genesis. England: Sheffield Academic Press.

HORRELL, D.G., HUNT, C. \& SOUTHGATE, C. 2008. Appeals to the Bible in ecotheology and environmental ethics: a typology of hermeneutical stances. Studies in Christian Ethics, 21:219-238.

HUONG, T.T.T. 2010. Resource access and livelihood resilience. Unpublished D Phil thesis. Manitoba: University of Manitoba.

KATEMOPOLOUS, M. 2007-2010. The history of palm trees. http://www.gardenguides.com/79522-history-palm-trees.html. Date of access13 January 2015.

MALTHUS, T.R. 1798. An Essay on the Principle of Population as It Affects the Future Improvement of Society, with Remarks on the Speculations of Mr. Godwin, M. Condorcet, and Other Writers. London: J. Johnson.

MARSHALL, A. 1998. Christians and the environment - Study Guide (with revisions to October 2005). http://www.alanmarshall.org/essays/christians\&environment. htm Date of access 14 September 2014.

MASTIN, 2008. The basics of philosophy. http://www.philosophybasics.com/philosophers mill.html Date of access 5 January 2015.

MUNROE, M. 2001. The purpose and the power of God's Glory. Shippenburg: Destiny Image Publishers.
NEUHAUS, R.J. 1997. Christ and creation's longings. First Things, 78:20-25.

NOLAN, A. 2006. Jesus today: a spirituality of radical freedom. New York: Orbis Books.

O'DONOGHUE, R. 1993. Environment, development and environmental education: an environmental policy and curriculum initiative in formal education. Howick: Share-net.

REUMAN, J. 1992. Stewardship and the economy of God. Michigan: William B Eerdmans.

ROBINSON, B. \& WOLFSON, E. 1982. Environmental education: a manual for elementary educators. New York: Teachers College Press.

SCHAEFFER, F. 1970. Pollution and the death of man. London: Hodder \& Stoughton.

SHELL, L.M., GALLO, M.V. \& RAVENSCROFT, J. 2009. Environmental influences on human growth and development: historical review and case study of contemporary influences. Annals of Human Biology, 36(5):459-77.

TALIAFERRO, C. 2005. Vices and virtues in religious environmental ethics, in R. Sandler and P. Cafaro (eds.). Environmental virtue ethics. Lanham: Rowman \& Littlefield. 159-172.

TRAVIS, P., EGGER, D., DAVIS, P. \& MECHBAL, A. 2002. Towards better stewardship: concepts and critical issues. Geneva: World Health Organisation.

UNEP. 1972 Declaration of the United Nations Conference on the Human Environment. http://www.unep.org/Documents.Multilingual/Default.asp?documen$\underline{\text { tid }=97 \& \text { articleid }=1503}$ Date of access 1 January 2014.

UNEP. 1977. Tbilisi declaration. The role, objectives and characteristics of environmental education. http://www.gdrc.org/uem/ee/tbilisi.html Date of access 12 October 2013.

UNEP. 1998. Report of the Economic Options Committee, 1998 Assessment, United Nations Environment Programme, 1998. (ISBN 92-807-1727-8).

UNEP. 2006. World Environment Day: deserts and desertification. http://www.unep. org/wed/2006/english/ Date of access 23 January 2014.

UNEP. 2012. Annual Report. Nairobi: UNEP.

UNESCO-UNEP. 1978. The Tbilisi Declaration. Connect, III (1):1-8

UNESCO-UNEP. 1988. International strategy for action in the field of environmental education and training for the 1990s. UNESCO, Paris and Nairobi: UNEP.

WHITE, L. 1967. The historical roots of our ecological crisis. Science, 155:1203-1207. 